\title{
Antimicrobial Nanomaterials in the Food Industry
}

\author{
Antimikrobiální nanomateriály v potravinářství
}

\author{
Dagmar CHUDOBOVA ${ }^{1}$, Kristyna CIHALOVA ${ }^{1}$, Pavel KOPEL ${ }^{1,2}$, Branislav RUTTKAY-NEDECKY ${ }^{1,2}$, Marketa \\ VACULOVICOVA $^{1,2}$, Rene KIZEK ${ }^{1,2}$, Vojtech ADAM $^{1,2 *}$ \\ ${ }^{1}$ Department of Chemistry and Biochemistry, Faculty of Agronomy, Mendel University in Brno, Zemedelska 1, CZ-613 00 Brno, \\ Czech Republic \\ ${ }^{2}$ Central European Institute of Technology, Brno University of Technology, Technicka 3058/10, CZ-616 00 Brno, Czech Republic, \\ European Union \\ * Corresponding author, e-mail: vojtech.adam@mendelu.cz
}

Reviewed paper / Recenzovaný článek

\begin{abstract}
Chudobova, D. - Cihalova, K. - Kopel, P. - Ruttkay-Nedecky, B. - Vaculovicova, M. - Kizek, R. - Adam, V.: Antimicrobial nanomaterials in the food industry. Kvasny Prum. 61, 2015, No. 2, p. 51-56

Nanoparticles of metals interacting with cellular components and biomacromolecules including DNA and RNA alter cellular processes. Concerning the antimicrobial activity, the metal nanoparticles in nanomolar concentrations inhibit the growth of bacterial strains. Even though the general mechanism of metal nanoparticle action has not been fully understood yet, among current accepted schemes belong the damage of the microbial enzymes by the release of metal ions, the membrane integrity changes, penetration into the cytoplasm of bacteria and accumulation in the periplasmic space or the reactive oxygen species formation due to the effect of metal nanoparticles. Moreover, G+ bacteria react remarkably later on the effect of metal nanoparticles compared to G- bacteria, which is reflected in the later inhibition of cell division. The aim of this study is to describe the properties of metal nanoparticles (silver, selenium, copper or zinc nanoparticles) and to compare their antimicrobial properties in complex with chitosan on the bacterial strains Staphylococcus aureus and Escherichia coli.
\end{abstract}

Chudobova, D. - Cihalova, K. - Kopel, P. - Ruttkay-Nedecky, B. - Vaculovicova, M. - Kizek, R. - Adam, V.: Antimikrobiální nanomateriály v potravinár̆ství. Kvasny Prum. 61, 2015, č. 2, s. 51-56

Kovové nanočástice interakcemi s buněčnými částicemi a biomakromulekulami včetně DNA a RNA pozměňují buněčné procesy. Pokud jde o antimikrobiální aktivitu, kovové nanočástice $v$ nanomolárních koncentracích inhibují růst bakteriálních kmenů. Přestože obecný mechanismus účinků kovových nanočástic dosud nebyl plně poznán, v současnosti je mezi nimi uznáváno poškození mikrobiálních enzymů uvolněním kovových iontů, změny integrity membrán, průnik do cytoplazmy bakterií, hromadění v periplazmatickém prostoru či vytváření reaktivních forem kyslíku. Navíc, G+ bakterie reagují na př́tomnost kovových nanočástic ve srovnání s G- bakteriemi se znatelným zpožděním, což se projevuje v opožděné inhibici buněčných celkủ. Článek popisuje vlastnosti kovových nanočástic (stříbro, selen, zinek) a porovnává jejich antimikrobiální účinky v chitosanových komplexech na bakteriální kmeny Staphylococcus aureus a Escherichia coli.

Chudobova, D. - Cihalova, K. - Kopel, P. - Ruttkay-Nedecky, B. - Vaculovicova, M. - Kizek, R. - Adam, V.: Antimikrobielle Nanomaterialien in der Lebensmittelindustrie. Kvasny Prum. 61, 2015, Nr. 2, S. 51-56

In Interaktionen metallische Nanoteilchen mit Zellteilchen und Biomakromolekülen einschließlich DNA und RNA ändern die zellulären Prozesse. Hinsichtlich der antimikrobiellen Aktivität, metallische Nanoteilchen inhibieren Wachstum von Bakterienstämmen. Trotzdem das allgemeine Mechanismus Nanoteilchenwirkungen vollständig noch nicht identifiziert wurde, in Gegenwart die Beschädigung mikrobiellen Enzymen durch Metallionenfreilegung, Membranintegritätänderungen, Penetration in Bakterienzytoplasma, Anhäufung im periplasmatischen Raum oder reaktive Sauerstoffspezies wurde schon anerkannt. Im Vergleich mit G- Bakterien reagieren G+ Bakterien auf die Gegenwart von metallischen Nanoteilchen mit einer wesentlichen Verspätung, was spiegelt sich in einer verzögerten Inhibition des Ganzkeimes. Im Artikel werden die Eigenschaften der metallischen Nanoteilchen (Silber, Selen, Zink) und vergleicht ihre mikrobielle Wirkungen in den Chitosan Komplexen auf die Bakterienstämmen Staphylococcus aureus und Escherichia coli.

Keywords: food industry, metal nanoparticles, bacteria, toxicity Klíčová slova: potravinářství, kovové nanočástice, bakterie, toxicita

\section{NANOTECHNOLOGIES AND THEIR} APPLICATIONS IN THE FOOD INDUSTRY

The massive industrial production and application of engineered nanomaterials ENMs currently and the predicted increase in the near future may result in their appearance in various environments, yielding the possibility of human exposure to these ENMs through inhalation, dermal contact, or ingestion (Martirosyan, Schneider, 2014). The amount of released of ENMs into the environment cannot be accurately estimated due to the speed of production, lack of knowledge on the amount of ENMs applied and released from various applications and products. Due to high-volume production of consumer products containing ENMs, such as nanoparticles (NPs) of silver, titanium dioxide, zinc oxide, silica, etc., human exposure to these artificial NPs is possible directly (via personal healthcare products, cosmetics, food, water, drinking, drugs and drug delivery system) and/or indirectly, e.g., through the release of these compounds into the environment (Cassee et al., 2011; Hansen et al., 2008; Mueller, Nowack, 2008; Smita et al., 2012). The indirect exposure may potentially result in the contamination water sources and uptake into the human food chain (Klaine et al., 2008).
Wide field benefiting from nanomaterial development is the food industry with big potentials for food safety, quality, and preservation (shelf-life extension) (Cho et al., 2008). In the food sector, the uses of nanotechnology-derived food ingredients, additives, supplements and contact materials are expected to grow rapidly. It was estimated that between 150-600 nanofoods and 400-500 nanofood packaging applications are already present on the market. Two hundred four products have been indicated, while according to potential exposure pathways into the human body from a theoretically there are 107 products potentially to be ingested (Martirosyan, Schneider, 2014).

The application of ENMs in the agri-food industry may represent new indirect sources of food contamination, as may arise from e.g. nano-sized pesticides and veterinary medicines, contact of food with nanoparticulate-based coatings during preparation or processing, or potential transport of ENMs from food packaging. Several pesticide formulations based on microemulsion or microencapsulation (Chaudhry et al., 2008) are known examples. Literature review on nanopesticides was published recently combining the existing information and draws conclusions that the nanoformulations expected to have significant impacts on the fate of active ingredients and/or introduction of new ingredients for which the environmental fate is still poorly understood (e.g. AgNPs) (Kah et al., 2013; Landsiedel et al., 2012). Taking into account the lack of knowledge of the environmental behaviour and the fate of ENMs, it is difficult to evaluate whether ENMs may accumulate in the food chain. 
In this review, we summarized data on metal-based nanoparticles exhibiting antimicrobial effects, and potentially applicable in various areas including food protection.

\section{SYNTHESIS, CHARACTERIZATION AND MODIFICATION OF METAL NANOPARTICLES}

Recently, magnetic nanoparticles have become a very powerful tool in a number of research areas such as biotechnology, biomedicine, and magnetic resonance imaging, in waste water treatment or information technology. The superparamagnetic nanoparticles have a rapid response to the applied external magnetic field. They will randomize their directions and become neutral again almost immediately after the field removed because the thermal energy will flip the dipoles in random directions (Jeong et al., 2007; Lu et al., 2007). The main critical parameters determining their use in biomedical applications is the magnetic particle size, biocompatibility or monodispersity (Tartaj et al., 2003). Methods such as thermal decomposition co-precipitation, sol-gel or microwave synthesis or/and microemulsion belong to ways of synthesis of a variety of NPs. Iron oxides (either $\mathrm{Fe}_{3} \mathrm{O}_{4}$ or $\mathrm{Y}-\mathrm{Fe}_{2} \mathrm{O}_{3}$ ) are commonly synthetized from aqueous $\mathrm{Fe}^{2+} / \mathrm{Fe}^{3+}$ salt solutions by co-precipitation after addition of a base under an inert atmosphere at room or elevated temperature (Lu et al., 2007). Ultra-small magnetite particles $(2-4 \mathrm{~nm}$ ) are prepared by the reaction of aqueous solutions of $\mathrm{FeCl}_{3}$ and $\mathrm{FeCl}_{2}$ with a concentration ratio of 2:1 and drop-by-drop addition into 200 $\mathrm{ml}$ of an alkali solution under dynamic stirring for (40 min at 20, 40,60 or $80^{\circ} \mathrm{C}$ ). Particles exhibit high crystallinity and superparamagnetism (Wu et al., 2008). Nigam et al. developed a single step process for preparation of colloidal magnetic nanoparticles of $\mathrm{Fe}_{3} \mathrm{O}_{4}$ stabilized by citric acid. Citrate-functionalized magnetic nanoparticles could provide an elegant tool for hyperthermia treatment. Positively charged drugs can be trapped onto the surface of negatively charged nanoparticles through electrostatic interactions. Drug molecules can be subsequently released due to the acidic environment present inside of the tumour (Behdadfar et al., 2012; Nigam et al., 2011).

Thermal decomposition is another synthesis route for preparation of nanoparticles with smaller size. For example, the uniform magnetic nanoparticles can be prepared by decomposing metal acetylacetonates in high-boiling organic solvents in the presence of stabilizing surfactants. (Behdadfar et al., 2012; Roca et al., 2006).

Hydrothermal reduction has been used for aqueous synthesis of magnetic nanoparticles $(9 \mathrm{~nm})$ in the presence of citric acid as a non-expensive and non-toxic reducing agent and stabilizer (Behdadfar et al., 2012).

Magnetic nanoparticles possess hydrophobic surfaces with a large surface area to volume ratio. Agglomeration caused by hydrophobic interaction results in increased particle size and thus, loss of superparamagnetic properties. Therefore, coating is required for effective stabilization of magnetic nanoparticles. The coating also provides essential properties for subsequent bioconjugation and additional functionalization. Numerous biomolecules such as targeting ligands, proteins, antibodies, etc., may be immobilized to the nanoparticle surface via amide or ester bonds to make the particles target-specific (Akbarzadeh et al., 2012).

In general, synthesis of different kinds of nanoparticles is as follows. Any procedure starts with a mixture of metal salts and usually capping ligands, after which the addition of a reducing agent or a change in $\mathrm{pH}$ causes the formation of nanoparticles. Sometimes light irradiation, heating or microwaves is required. The syntheses of aqueous AuNPs are based on the Turkevich method. A solution of chloroauric acid is heated to boiling and sodium citrate is added. It reduces the gold ions and nanoparticles are formed in a few minutes. Particles with narrow-sized distribution are formed depending on conditions, in sizes from 15 to $150 \mathrm{~nm}$ (Frens, 1973). The citrate-capped gold nanoparticles are extremely stable; however desired coating material can be employed to provide stable, biocompatible nanoparticles. The Turkevich method can be modified and thus, nanoparticles of different shapes, such as nanorods or stars, can be prepared (Jana et al., 2001; Nehl et al., 2006). Gadolinium complex of cysteine diethylenetriaminepentaacetic acid (DTPA) may be utilized to create gold nanoparticles as sulphur binds to gold very strongly (Park et al., 2010). Similarly, MRI-active gold nanoparticles were also prepared by this method (Alric et al., 2008; Cormode et al., 2013; Park et al., 2008).
Even though numerous preparation ways have been developed (Mahl et al., 2012), the synthesis using non-toxic and environmentally friendly means is attractive especially for medical application. Number of methods has been designed for biological or biogenic synthesis of nanoparticles from salts of corresponding metals. Thus microorganisms, plants, plant tissue and fruits, plant extracts and marine algae can be used to produce nanoparticles. The reducing agents involved numerous water soluble plant metabolites (e.g. alkaloids, phenolic compounds, terpenoids) and co-enzymes. Silver and gold nanoparticles have been the particular focus of plant-based syntheses. Extracts of a diverse range of plant species have been successfully used in making nanoparticles (Mittal et al., 2013).

\section{BIOCHEMICAL MECHANISM OF TOXICITY TO PROKARYOTIC CELLS}

Metal nanoparticles represent also a tool for protection against bacterial infection. Bacterial infection is a huge threat for the human body and its immune system. It can lead to the removal of extremities. Bacterial infections are caused by a wide range of pathogenic bacteria like Staphylococcus (its resistant varieties MRSA, VRSA), Escherichia coli, Streptococcus. Staphylococci exhibiting resistance to number of antibiotic drugs such as $\beta$-lactam antibiotics; especially dangerous varieties are the methicillin-resistant Staphylococcus aureus (MRSA), vancomycin-resistant Staphylococcus aureus (VRSA). Because of increasing resistance of bacteria, it is necessary to focus research on finding new antimicrobial drugs (Chudobova et al., 2014b). The substitution for an antibiotic must be bactericidal and safe for the human body at the same time. The mechanism of inhibition must differ from the antibiotic.

The toxicity of metal particles is due to the interaction of specific metals with cell structures (Rouch et al., 1995). Metals enter the cell via two different ways (Nies and Silver, 1995). Non-specific transporters allowing metals to enter the cell via the chemiosmotic gradient are also capable of heavy metal transport. (Schreurs and Rosenberg, 1982). This way provides rapid transport of the metal to the cells through the plasmatic membrane (Nieboer and Richardson, 1980). This system is called "open gate" and it explains the cause of metal toxicity. Another way of metal transport is specific, it is slower than "open gate," consumes energy and is only used when needed (lack of nutrients) (Nies, 1999). Lipid peroxidation is the main mechanism of metal toxicity which involves a reaction of oxygen with polyunsaturated fatty acids (parts of cell membrane), resulting in formation of oxygen radicals which interact with other structures of cells damaged them. Toxic oxygen radicals are highly reactive and interact with all biomolecules in the immediate vicinity. Ions of iron change enzymatic specificity using conduction conformation, leading to a decrease or increase in enzymatic activity. Nanoparticles interact with biomolecules such as polysaccharides and proteins. Properties of both substances can be combined.

\section{ANTIBACTERIAL EFFECT OF METAL NANOPARTICLES IN COMPLEX WITH CHITOSAN}

Nanotechnology enables to design, manipulate and model functionalities on the nanometre scale. It includes the investigation of nanoparticles with size less than $100 \mathrm{~nm}$. Those particles with an antimicrobial function have received substantial attention within a range of diverse areas, including medicine and dentistry. In theory, high volume-surface ratio and nanometer size allow them to interact with microbial membranes and thus, elicit an antimicrobial effect that is not solely due to the release of metal ions (Allaker and Memarzadeh, 2014).

Metal nanoparticles interact with cellular components (DNA, RNA and ribosomes), deactivate the cellular processes (Das et al., 2013). Even nanomolar concentrations of nanoparticles exhibit excellent antibacterial activity. It is essential to obtain the correct dimensions and avoid agglomeration, significantly reducing the antimicrobial effect. Metal nanoparticles displayhigher antimicrobial effect on $\mathrm{G}^{+}$ bacteria than on $G^{-}$bacteria. The effect is reflected in the inhibition of cell division.

\subsection{Chitosan}

Chitosan is a cationic polysaccharide polymer composed of glucosamine and $\mathrm{N}$-acetyl glucosamine linked with a $\beta$-1-4-glycosidic 
linkage obtained from chitin by deacetylation of chitin in the presence of an alkali (Bonilla et al., 2013; Crini and Badot, 2008). Chitin is a biopolymer presented in the exoskeleton of crustaceans such as crabs, shrimps and crawfish (Andrews et al., 2002; Choi et al., 2001). The positive charge results in numerous physiological and biological properties (Honary et al., 2011). It is a biocompatible polymer that can be degraded by enzymes in the human body to non-toxic. Chitosan films and complexes have a great potential to be used as active material in medicine due to their antimicrobial activity, non-toxicity and low permeability to oxygen (Kanatt et al., 2012). The concept has attracted considerable interest due to its antimicrobial and antitumor activities, and its immune enhancing effects (Jeon et al., 2001; No et al., 2002; Suzuki et al., 1986).

The exact mechanism for the antibacterial activity is not yet fully understood, some studies have suggested that a positive charge on the $\mathrm{NH}_{3}{ }^{+}$group of the glucosamine monomer at $\mathrm{pH}<$ 6.3 allows interactions with negatively-charged microbial cell membranes that lead to the leakage of intracellular constituents (Helander et al., 2001; Liu et al., 2004; Papineau et al., 1991; Sudarshan et al., 1992).

In contrary, some studies propose that the antimicrobial activity is caused due to the binding to the negatively-charged bacterial cell wall followed by attachment to the DNA (Kurita et al., 1993). Also the effect of molecular weight and concentration of used chitosan plays a key role on the antimicrobial activity (Honary et al., 2011; Sanchez-Gonzalez et al., 2011). To enhance the bioactivity chitosan is often connected to other biologically active materials including drugs.

In the study of Banerjee et al.(Banerjee et al., 2010), synergy in the antimicrobial activity of a chitosan-silver nanoparticle (CS-AgNPs) composite in the presence of molecular iodine was reported. Green fluorescent protein expressed in recombinant Escherichia coli bacteria has been used to investigate the efficacy and to suggest the mechanism of action. A significantly high bactericidal activity of the nanocomposite in the presence of iodine than either due to the composite, chitosan, AgNPs or iodine only has been found. Transmission electron microscopy measurements revealed the attachment of bacteria to the composite. Additionally, flow cytometry results confirmed the occurrence of cell wall damage of the bacteria treated with the composite in the presence of iodine. Furthermore, the nanocomposite and iodine combination was found to employ reactive oxygen species generated oxidative stress in the cytoplasm of bacterial cells. Elucidation of the mechanism of synergy due to three potential antibacterial components suggested that on the surface of AgNPs molecular iodine possibly generated iodine atom thus, contributing toward free radically-induced oxidative stress, whereas chitosan and AgNPs facilitated the process of cell killing and thus, collectively enhanced the potency of the antimicrobial effect at the lowest concentrations of individual components (Fig. 1).

Recently, Mathew et al. (Mathew and Kuriakose, 2013) investigated the antibacterial effect of silver nanoparticle-encapsulated in chitosan which was carried out against Staphylococcus aureus and Escherichia coli and against fungal species such as Aspergillus flavus and Aspergillus terreus. This research showed, that silver nanoparticle-encapsulated in chitosan are applicable for antibacterial and antifungal purposes. Later, hybrid $\mathrm{ZnO} /$ Chitosan nanoparticles were formed on cotton fabrics and exhibiting higher antimicrobial activity against Staphylococcus aureus and Escherichia coli when compared with ZnO NPs only (Petkova et al., 2014).

\subsection{Silver nanoparticles}

More than 1300 nanotechnology-enabled products have already entered the market. Silver is well known for its significant antimicrobial activity and therapeutic potential. By far, the most commonly utilized commercial nanomaterials are antimicrobial silver nanoparticles (AgNPs) (Ip et al., 2006; Klasen, 2000; Silver, 2003). The inactivation of numerous enzymes by silver ions released from silver nanoparticles has been proposed (Shi et al., 2004). Silver ions enter the bacteria, inhibit particular functions and damage the cell membrane. Even low concentrations of silver are very effective as a germicidal agent. The antimicrobial effect of silver ions or silver nanoparticles was confirmed by number of studies (Chudobova et al., 2014a; Chudobova et al., 2013a; Chudobova et al., 2013b).

There is a wide range of microorganisms that are sensitive to silver. Also a good potential for cancer treatment has been identified. Long exposure of eukaryotic cells to silver nanoparticles smaller than $20 \mathrm{~nm}$, affect them negatively. The combination of silver nanoparticles with biopolymer such as chitosan is a possible solution for its eukaryotic or prokaryotic toxicity (Chudobova et al., 2013b).

Silver nanoparticles possess high antibacterial activity against gram-positive and gram-negative bacteria and exhibit effective growth inhibiting properties for various microorganisms (Hetrick et al., 2008; Chudobova et al., 2014a; Chudobova et al., 2013a; Chudobova et al., 2013b). Effective biocidal concentration is at nanomolar in contrast of a micromolar level of silver ions. Silver particles without a coating are highly reactive and easily oxidized in the air; it leads to a loss of dispersibility and antimicrobial effect (Kim et al., 2007; Sharma et al., 2009).

\subsection{Selenium nanoparticles}

Selenium is an essential micro-mineral element that is relatively deficient in most areas of the world. It has a number of biological functions in the human organism. It forms selenocysteine, which is a part of the active centre of the glutathione peroxidase enzyme (Kryukov et al., 2003) and therefore the most important action is its antioxidant effect. It is a catalyst of the oxidation of glutathione and 
the reduction of hydrogen peroxide to water in these enzymes. It regulates metabolism, enhances reproductive performance, improves immunity, helps to resist to free radicals, prevents cancer, postpones aging, prevents some local epidemic diseases, and detoxicatates from some heavy metals (Mater et al., 2005; Navarro-Alarcon and Lopez-Martinez, 2000).

Selenium is a naturally occurring essential element, which is required for a healthy lifestyle and is recommended for daily intake by the FDA. A deficit of selenium is associated with an increased risk of mortality, poor immune functions and cognitive decline. Selenium particles are able to damage bacterial biofilm and inhibit bacterial growth (Chudobova et al., 2014a; Tran and Webster, 2011; Tran et al., 2009). Selenium atoms or complex substances can generate superoxide that is toxic to cancer cells, bacteria and viruses (Spallholz et al., 2001).

Materials modified by seleniumare able to provide antimicrobial properties (Chudobova et al., 2014a). It has been studied also for medical applications and for orthopaedic implants (Perla, Webster, 2005). Moreover, it has been investigated for various purposes such as anticancer applications. Selenium as a dietary supplement has been demonstrated to reduce the risks of various types of cancers including prostate cancer, lung cancer and oesophageal and gastric-cardiac cancers (Clark et al., 1996; Clark et al., 1998; Rayman, 2005; Wei et al., 2004; Yang et al., 2009). Probiotics enriched by selenium have been demonstrated to significantly inhibit the growth of pathogenic Escherichia coli in vivo and in vitro.

\subsection{Copper nanoparticles}

Also copper nanoparticles reveal extraordinary behaviour as antibacterial and antimicrobial agents (Majzlik et al., 2011; Majzlik et al., 2010). The most commonly used substrates are polymeric beads prepared from methacrylic acid and divinylbenzene, silica-coated hollow polystyrene beads, polystyrene - divinylbenzene ion exchangers (PS-DVB), activated carbon granules, carbon aerogels and silica beads. These substrates have been impregnated ex situ with metal nanoparticles (Khare et al., 2014). These nanoparticles play a double role: (1) they enhance the porosity (internal surface area and pore volume) in the beads such that the dispersed AgNPs in the beads are relatively more accessible to bacteria and (2) they act as an antibacterial agent, although less effectively than other metal nanoparticles, (Khare et al., 2014).

Antimicrobial properties of copper are weaker compared to silver. It may have a similar principle of action, however, the precise mechanism remains unclear. But the copper may interact with the $-\mathrm{SH}$ groups of key microbial enzymes. Studies demonstrated superior antimicrobial activity with copper nanoparticles against Escherichia coli and spore-forming Bacillus subtilis compared with silver nanoparticles. (Allaker and Memarzadeh, 2014).

Recently, silver nanoparticles were also used to dope $\mathrm{TiO}_{2}$ photocatalyst to provide bacterial (Escherichia coli) disinfection under visible light irradiation. However, silver nanoparticles are rare and expensive therefore copper-doped $\mathrm{TiO}_{2}$ photocatalyst may serve without a significant decrease in the disinfection activity and could contribute to the development of cheaper photocatalysts for practical applications. Copper ions and copper nanoparticles have exhibited high antibacterial activity against a wide range of bacteria including Salmonella enterica, Campylobacter jejuni, Escherichia coli, Listeria monocytogenes, and Staphylococcus aureus. It an essential metal element for human health and is considered as non-toxic metal to the human organism (Pham, Lee, 2014).

Copper nanoparticles are relatively stable in terms of both chemical and physical properties and may be particularly valuable antimicrobial due to the extremely high surface areas and unusual crystal morphologies (Nezhad et al., 2014).

\subsection{Zinc nanoparticles}

Zinc is an important trace element. It shows attractive antimicrobial properties that are utilized in several pharmaceutical and cosmetic products. It is also an endogenous metal that is involved in many physiological processes. Zinc is involved in vivo in more than 300 enzymatic reactions (Haase et al., 2008). The proposed mechanisms of antibacterial activity with respect to zinc nanoparticles include the generation of reactive oxygen species and damage to the cell membrane with subsequent interaction of the nanoparticle with the intracellular contents (Allaker and Memarzadeh, 2014). Zinc is commonly used in the pharmaceutic industry as a carrying agent, smoothing agent and protective coating. It is frequently used to treat diaper rash, acne and minor burns (Arad et al., 1999). A great advantage of zinc is its low price and easy clearance (Sawai et al., 1998). The antimicrobial toxicity of zinc is due to the generation of hydrogen peroxide (Sawai et al., 1995).

Recent studies confirm the higher concentration of zinc nanoparticles for growth inhibition and the killing effect against a range of pathogens including Escherichia coli and MRSA.

\section{CONCLUSIONS}

The demand for antimicrobial agents with the same effect as antibiotic drugs rapidly increases. Metal nanoparticles dispose antimicrobial properties, which lead to reducing the risk of bacterial infection. Currently, testing for their antimicrobiality is incorporated into a range of studies in worldwide research groups. The potential toxicity of metal nanoparticles to eukaryotic cells can be solved by the formation of complexes with a biopolymer substance like chitosan. The future of nanotechnology and the use of metal nanoparticles in practice will be directed to ensure a maximal antimicrobial effect with minimal effects on the host organism.

\section{ACKNOWLEDGEMENTS}

Financial support from the following projects CEITEC CZ.1.05/1.1.00/02.0068 and TACR CK TE02000177is highly acknowledged.

\section{REFERENCES}

Akbarzadeh, A., Samiei, M., Davaran, S., 2012: Magnetic nanoparticles: preparation, physical properties, and applications in biomedicine. Nanoscale Res. Lett. 7:1-13. DOI 144 10.1186/1556-276x-7-144

Allaker, R.P., Memarzadeh, K., 2014: Nanoparticles and the control of oral infections. Int. J. Antimicrob. Agents. 43(2): 95-104. DOI 10.1016/j.ijantimicag.2013.11.002

Alric, C., Taleb, J., Le Duc, G., Mandon, C., Billotey, C., Le Meur-Herland, A., Brochard, T., Vocanson, F., Janier, M., Perriat, P., Roux, S., Tillement, O., 2008: Gadolinium chelate coated gold nanoparticles as contrast agents for both X-ray computed tomography and magnetic resonance imaging. J. Am. Chem. Soc. 130(18): 5908-5915. DOI 10.1021/ja078176p

Andrews, L.S., Keys, A.M., Martin, R.L., Grodner, R., Park, D.L., 2002: Chlorine dioxide wash of shrimp and crawfish an alternative to aqueous chlorine. Food Microbiol. 19(4): 261-267. DOI 10.1006/yfmic.493
Arad, A., Mimouni, D., Ben-Amitai, D., Zeharia, A., Mimouni, M., 1999: Efficacy of topical application of eosin compared with zinc oxide paste and corticosteroid cream for diaper dermatitis. Dermatology. 199(4): 319-322. DOI 10.1159/000018282

Banerjee, M., Mallick, S., Paul, A., Chattopadhyay, A., Ghosh, S.S., 2010: Heightened reactive oxygen species generation in the antimicrobial activity of a three component iodinated chitosan-silver nanoparticle composite. Langmuir. 26(8): 5901-5908. DOI 10.1021/la9038528

Behdadfar, B., Kermanpur, A., Sadeghi-Aliabadi, H., Morales, M.D., Mozaffari, M., 2012: Synthesis of high intrinsic loss power aqueous ferrofluids of iron oxide nanoparticles by citric acid-assisted hydrothermal-reduction route. J. Solid State Chem. 187:20-26. DOI 10.1016/j.jssc.2011.12.011

Bonilla, J., Atares, L., Vargas, M., Chiralt, A., 2013: Properties of wheat starch film-forming dispersions and films as affected by 
chitosan addition. J. Food Eng. 114(3): 303-312. DOI 10.1016/j. jfoodeng.2012.08.005

Cassee, F.R., van Balen, E.C., Singh, C., Green, D., Muijser, H., Weinstein, J., Dreher, K., 2011: Exposure, Health and Ecological Effects Review of Engineered Nanoscale Cerium and Cerium Oxide Associated with its Use as a Fuel Additive. Crit. Rev. Toxicol. 41(3): 213-229. DOI 10.3109/10408444.2010.529105

Clark, L.C., Combs, G.F., Turnbull, B.W., Slate, E.H., Chalker, D.K. Chow, J., Davis, L.S., Glover, R.A., Graham, G.F., Gross, E.G., Krongrad, A., Lesher, J.L., Park, H.K., Sanders, B.B., Smith, C.L., Taylor, J.R., 1996: Effects of selenium supplementation for cancer prevention in patients with carcinoma of the skin a randomized controlled trial - A randomized controlled trial. JAMA-J. Am. Med. Assoc. 276(24): 1957-1963. DOI 10.1001/jama.276.24.1957

Clark, L.C., Dalkin, B., Krongrad, A., Combs, G.F., Turnbull, B.W., Slate, E.H., Witherington, R., Herlong, J.H., Janosko, E., Carpenter, D., Borosso, C., Falk, S., Rounder, J., 1998: Decreased incidence of prostate cancer with selenium supplementation: Results of a double-blind cancer prevention trial. Br. J. Urol. 81(5): 730-734.

Cormode, D.P., Sanchez-Gaytan, B.L., Mieszawska, A.J., Fayad, Z.A., Mulder, W.J.M., 2013: Inorganic nanocrystals as contrast agents in MRI: synthesis, coating and introduction of multifunctionality. NMR Biomed. 26(7): 766-780. DOI 10.1002/nbm.2909

Crini, G., Badot, P.M., 2008: Application of chitosan, a natural aminopolysaccharide, for dye removal from aqueous solutions by adsorption processes using batch studies: A review of recent literature. Prog. Polym. Sci. 33(4): 399-447. DOI 10.1016/j.progpolymsci.2007.11.001

Das, M.R., Sarma, R.K., Borah, S.C., Kumari, R., Saikia, R., Deshmukh, A.B., Shelke, M.V., Sengupta, P., Szunerits, S., Boukherroub, R., 2013: The synthesis of citrate-modified silver nanoparticles in an aqueous suspension of graphene oxide nanosheets and their antibacterial activity. Colloid Surf. B-Biointerfaces. 105:128-136.

Frens, G., 1973: Controlled nucleation for regulation of particles-size in monodisperse gold suspensions. Nature. 241(105): 20-22. DOI

Haase, H., Overbeck, S., Rink, L., 2008: Zinc supplementation for the treatment or prevention of disease: Current status and future perspectives. Exp. Gerontol. 43(5): 394-408. DOI 10.1016/j.exger.2007.12.002

Hansen, S.F., Michelson, E.S., Kamper, A., Borling, P., Stuer-Lauridsen, F., Baun, A., 2008: Categorization framework to aid exposure assessment of nanomaterials in consumer products. Ecotoxicology. 17(5): 438-447. DOI 10.1007/s10646-008-0210-4

Helander, I.M., Nurmiaho-Lassila, E.L., Ahvenainen, R., Rhoades, J., Roller, S., 2001: Chitosan disrupts the barrier properties of the outer membrane of Gram-negative bacteria. Int. J. Food Microbiol. 71(2-3): 235-244. DOI 10.1016/s0168-1605(01)00609-2

Hetrick, E.M., Shin, J.H., Stasko, N.A., Johnson, C.B., Wespe, D.A., Holmuhamedov, E., Schoenfisch, M.H., 2008: Bactericidal efficacy of nitric oxide-releasing silica nanoparticles. ACS Nano. 2(2): 235-246. DOI 10.1021/nn700191

Honary, S., Ghajar, K., Khazaeli, P., Shalchian, P., 2011: Preparation, characterization and antibacterial properties of silver-chitosan nanocomposites using different molecular weight grades of chitosan. Trop. J. Pharm. Res. 10(1): 69-74.

Chaudhry, Q., Scotter, M., Blackburn, J., Ross, B., Boxall, A., Castle, L., Aitken, R., Watkins, R., 2008: Applications and implications of nanotechnologies for the food sector. Food Addit. Contam. Part A-Chem. 25(3): 241-258. DOI 10.1080/02652030701744538

Cho, Y.J., Kim, C.J., Kim, N., Kim, C.T., Park, B., 2008: Some cases in applications and agricultural systems of nanotechnology to food. BioChip J. 2(3): 183-185.

Choi, B.K., Kim, K.Y., Yoo, Y.J., Oh, S.J., Choi, J.H., Kim, C.Y., 2001: In vitro antimicrobial activity of a chitooligosaccharide mixture against Actinobacillus actinomycetemcomitans and Streptococcus mutans. Int. J. Antimicrob. Agents. 18(6): 553-557. DOI 10.1016/s0924-8579(01)00434-4

Chudobova, D., Cihalova, K., Dostalova, S., Ruttkay-Nedecky, B., Merlos, M.A.R., Tmejova, K., Kopel, P., Nejdl, L., Kudr, J., Gumulec, J., Krizkova, S., Kynicky, J., Kizek, R., Adam, V., 2014a: Comparison of the effects of silver phosphate and selenium nanoparticles on Staphylococcus aureus growth reveals potentia for selenium particles to prevent infection FEMS Microbiol. Lett. 351(2): 195-201.

Chudobova, D., Dobes, J., Nejdl, L., Maskova, D., Merlos, M.A.R., Ruttkay-Nedecky, B., Zitka, O., Krystofova, O., Kynicky, J., Konecna, M., Pohanka, M., Hubalek, J., Zehnalek, J., Klejdus, B., Kizek, R., Adam, V., 2013a: Oxidative stress in Staphylococcus aureus treated with silver(I) ions revealed by spectrometric and voltammetric assays. Int. J. Electrochem. Sci. 8(4): 4422-4440.

Chudobova, D., Dostalova, S., Blazkova, I., Michalek, P., Ruttkay-Nedecky, B., Sklenar, M., Nejdl, L., Kudr, J., Gumulec, J., Tmejova, K., Konecna, M., Vaculovicova, M., Hynek, D., Masarik, M., Kynicky, J., Kizek, R., Adam, V., 2014b: Effect of ampicillin, streptomycin, penicillin and tetracycline on metal resistant and non-resistant Staphylococcus aureus. Int. J. Environ. Res. Pub. Health. 11(3): 3233-3255

Chudobova, D., Nejdl, L., Gumulec, J., Krystofova, O., Merlos, M.AR., Kynicky, J., Ruttkay-Nedecky, B., Kopel, P., Babula, P., Adam, V., Kizek, R., 2013b: Complexes of silver(I) ions and silver phosphate nanoparticles with hyaluronic acid and/or chitosan as promising antimicrobial agents for vascular grafts. Int. J. Mol. Sci. 14(7): 13592-13614.

Ip, M., Lui, S.L., Poon, V.K.M., Lung, I., Burd, A., 2006: Antimicrobial activities of silver dressings: an in vitro comparison. J. Med. Microbiol. 55(1): 59-63. DOI 10.1099/jmm.0.46124-0

Jana, N.R., Gearheart, L., Murphy, C.J., 2001: Wet chemical synthesis of high aspect ratio cylindrical gold nanorods. J. Phys. Chem. B. 105(19): 4065-4067. DOI 10.1021/jp0107964

Jeon, Y.J., Park, P.J., Kim, S.K., 2001: Antimicrobial effect of chitooligosaccharides produced by bioreactor. Carbohydr. Polym. 44(1): 71-76. DOI 10.1016/s0144-8617(00)00200-9

Jeong, U., Teng, X.W., Wang, Y., Yang, H., Xia, Y.N., 2007: Superparamagnetic colloids: Controlled synthesis and niche applications. Adv. Mater. 19(1): 33-60. DOI 10.1002/adma.200600674

Kah, M., Beulke, S., Tiede, K., Hofmann, T., 2013: Nanopesticides: State of Knowledge, Environmental Fate, and Exposure Modeling. Crit. Rev. Environ. Sci. Technol. 43(16): 1823-1867. DOI 10.1080/10643389.2012.671750

Kanatt, S.R., Rao, M.S., Chawla, S.P., Sharma, A., 2012: Active chitosan-polyvinyl alcohol films with natural extracts. Food Hydrocolloids. 29(2): 290-297. DOI 10.1016/j.foodhyd.2012.03.005

Khare, P., Sharma, A., Verma, N., 2014: Synthesis of phenolic precursor-based porous carbon beads in situ dispersed with copper-silver bimetal nanoparticles for antibacterial applications. J. CoIloid Interface Sci. 418:216-224. DOI 10.1016/j.jcis.2013.12.026

Kim, J.S., Kuk, E., Yu, K.N., Kim, J.H., Park, S.J., Lee, H.J., Kim, S.H., Park, Y.K., Park, Y.H., Hwang, C.Y., Kim, Y.K., Lee, Y.S., Jeong, D.H., Cho, M.H., 2007: Antimicrobial effects of silver nanoparticles. Nanomed.-Nanotechnol. Biol. Med. 3(1): 95-101. DOI 10.1016/j.nano.2006.12.001

Klaine, S.J., Alvarez, P.J.J., Batley, G.E., Fernandes, T.F., Handy, R.D., Lyon, D.Y., Mahendra, S., McLaughlin, M.J., Lead, J.R., 2008: Nanomaterials in the environment: Behavior, fate, bioavailability, and effects. Environ. Toxicol. Chem. 27(9): 1825-1851. DOI 10.1897/08-090.1

Klasen, H.J., 2000: A historical review of the use of silver in the treatment of burns. II. Renewed interest for silver. Burns. 26(2): 131-138. DOI 10.1016/s0305-4179(99)00116-3

Kryukov, G.V., Castellano, S., Novoselov, S.V., Lobanov, A.V., Zehtab, O., Guigo, R., Gladyshev, V.N., 2003: Characterization of mammalian selenoproteomes. Science. 300(5624): 1439-1443. DOI 10.1126/science.1083516

Kurita, K., Tomita, K., Tada, T., Nishimura, S., Ishii, S., 1993: Reactivity characteristics of a new form of chitosan - facile n-phthaloylation of chitosan prepared from squid beta-chitin for effective solubilization. Polym. Bull. 30(4): 429-433. DOI 10.1007/bf00338476

Landsiedel, R., Fabian, E., Ma-Hock, L., Wohlleben, W., Wiench, K., Oesch, F., van Ravenzwaay, B., 2012: Toxico-/biokinetics of nanomaterials. Arch. Toxicol. 86(7): 1021-1060. DOI 10.1007/ s00204-012-0858-7

Liu, H., Du, Y.M., Wang, X.H., Sun, L.P., 2004: Chitosan kills bacteria through cell membrane damage. Int. J. Food Microbiol. 95(2): 147-155. DOI 10.1016/j.ijfoodmicro.2004.01.022

Lu, A.H., Salabas, E.L., Schuth, F., 2007: Magnetic nanoparticles: Synthesis, protection, functionalization, and application. Angew. Chem.-Int. Edit. 46(8): 1222-1244. DOI 10.1002/anie.200602866

Mahl, D., Diendorf, J., Ristig, S., Greulich, C., Li, Z.A., Farle, M., Koller, M., Epple, M., 2012: Silver, gold, and alloyed silver-gold nanoparticles: characterization and comparative cell-biologic action. J. Nanopart. Res. 14(10): 1-6. DOI 115310.1007/s11051012-1153-5

Majzlik, P., Strasky, A., Adam, V., Nemec, M., Trnkova, L., Zehnalek, J., Hubalek, J., Provaznik, I., Kizek, R., 2011: Influence of zinc(II) and copper(II) lons on Streptomyces bacteria revealed by electrochemistry. Int. J. Electrochem. Sci. 6(6): 2171-2191. 
Majzlik, P., Strasky, A., Nemec, M., Trnkova, L., Havel, L., Zehnalek, J., Babula, P., Kizek, R., 2010: Remediation potential of bacteria for removing heavy metals from environment. Listy Cukrov. Reparske. 126(11): 414-415.

Martirosyan, A., Schneider, Y.J., 2014: Engineered Nanomaterials in Food: Implications for Food Safety and Consumer Health. Int. J. Environ. Res. Public Health. 11(6): 5720-5750. DOI 10.3390/ ijerph110605720

Mater, D.D.G., Bretigny, L., Firmesse, O., Flores, M.J., Mogenet, A., Bresson, J.L., Corthier, G., 2005: Streptococcus thermophilus and Lactobacillus delbrueckii subsp bulgaricus survive gastrointestinal transit of healthy volunteers consuming yogurt. FEMS Microbiol. Lett. 250(2): 185-187. DOI 10.1016/j.femsle.2005.07.006

Mathew, T.V., Kuriakose, S., 2013: Photochemical and antimicrobial properties of silver nanoparticle-encapsulated chitosan functionalized with photoactive groups. Mater. Sci. Eng. C-Mater. Biol. Appl. 33(7): 4409-4415. DOI 10.1016/j.msec.2013.06.037

Mittal, A.K., Chisti, Y., Banerjee, U.C., 2013: Synthesis of metallic nanoparticles using plant extracts. Biotechnol. Adv. 31(2): 346356. DOI 10.1016/j.biotechadv.2013.01.003

Mueller, N.C., Nowack, B., 2008: Exposure modeling of engineered nanoparticles in the environment. Environ. Sci. Technol. 42(12): 4447-4453. DOI 10.1021/es7029637

Navarro-Alarcon, M., Lopez-Martinez, M.C., 2000: Essentiality of selenium in the human body: relationship with different diseases. Sci. Total Environ. 249(1-3): 347-371. DOI 10.1016/s00489697(99)00526-4

Nehl, C.L., Liao, H.W., Hafner, J.H., 2006: Optical properties of star-shaped gold nanoparticles. Nano Lett. 6(4): 683-688. DOI 10.1021/nl052409y

Nezhad, S.S., Khorasgani, M.R., Emtiazi, G., Yaghoobi, M.M., Shakeri, S., 2014: Isolation of copper oxide (CuO) nanoparticles resistant Pseudomonas strains from soil and investigation on possible mechanism for resistance. World J. Microbiol. Biotechnol. 30(3): 809-817. DOI 10.1007/s11274-013-1481-3

Nieboer, E., Richardson, D.H.S., 1980: The replacement of the non-descript term heavy-metals by a biologically and chemically significant classification of metal-ions. Environ. Pollut. Series B-Chem. Phys. 1(1): 3-26. DOI 10.1016/0143-148x(80)90017-8

Nies, D.H., 1999: Microbial heavy-metal resistance. Appl. Microbiol. Biotechnol. 51(6): 730-750.

Nies, D.H., Silver, S., 1995: Ion efflux systems involved in bacterial metal resistances. J. Indust. Microbiol. 14(2): 186-199. DOI 10.1007/bf01569902

Nigam, S., Barick, K.C., Bahadur, D., 2011: Development of citrate-stabilized Fe3O4 nanoparticles: Conjugation and release of doxorubicin for therapeutic applications. J. Magn. Magn. Mater. 323(2): 237-243. DOI 10.1016/j.jmmm.2010.09.009

No, H.K., Park, N.Y., Lee, S.H., Meyers, S.P., 2002: Antibacterial activity of chitosans and chitosan oligomers with different molecular weights. Int. J. Food Microbiol. 74(1-2): 65-72. DOI 10.1016/ s0168-1605(01)00717-6

Papineau, A.M., Hoover, D.G., Knorr, D., Farkas, D.F., 1991: Antimicrobial effect of water-soluble chitosans with high hydrostatic-pressure. Food Biotechnol. 5(1): 45-57.

Park, J.A., Kim, H.K., Kim, J.H., Jeong, S.W., Jung, J.C., Lee, G.H., Lee, J., Chang, Y., Kim, T.J., 2010: Gold nanoparticles functionalized by gadolinium-DTPA conjugate of cysteine as a multimodal bioimaging agent. Bioorg. Med. Chem. Lett. 20(7): 2287-2291. DOI 10.1016/j.bmcl.2010.02.002

Park, J.A., Reddy, P.A.N., Kim, H.K., Kim, I.S., Kim, G.C., Chang, Y., Kim, T.J., 2008: Gold nanoparticles functionalised by Gd-complex of DTPA-bis(amide) conjugate of glutathione as an MRI contrast agent. Bioorg. Med. Chem. Lett. 18(23): 6135-6137. DOI 10.1016/j.bmcl.2008.10.017

Perla, V., Webster, T.J., 2005: Better osteoblast adhesion on nanoparticulate selenium - A promising orthopedic implant material. J. Biomed. Mater. Res. Part A. 75A(2): 356-364. DOI 10.1002/ jbm.a.30423

Petkova, P., Francesko, A., Fernandes, M.M., Mendoza, E., Perelshtein, I., Gedanken, A., Tzanov, T., 2014: Sonochemical coating of textiles with hybrid $\mathrm{ZnO} /$ chitosan antimicrobial nanoparticles. ACS Appl. Mater. Interfaces. 6(2): 1164-1172. DOI 10.1021/ am404852d

Pham, T.D., Lee, B.K., 2014: Cu doped TiO2/GF for photocatalytic disinfection of Escherichia coli in bioaerosols under visible light irradiation: Application and mechanism. Appl. Surf. Sci. 296:15-23.
Rayman, M.P., 2005: Selenium in cancer prevention: a review of the evidence and mechanism of action. Proc. Nutr. Soc. 64(4): 527-542. DOI 10.1079/pns2005467

Roca, A.G., Morales, M.P., O‘Grady, K., Serna, C.J., 2006: Structural and magnetic properties of uniform magnetite nanoparticles prepared by high temperature decomposition of organic precursors. Nanotechnology. 17(11): 2783-2788. DOI 10.1088/09574484/17/11/010

Rouch, D.A., Lee, B.T.O., Morby, A.P., 1995: Understanding cellular-responses to toxic agents - a model for mechanism-choice in bacterial metal resistance. J. Indust. Microbiol. 14(2): 132-141. DOI 10.1007/bf01569895

Sanchez-Gonzalez, L., Chafer, M., Hernandez, M., Chiralt, A., Gonzalez-Martinez, C., 2011: Antimicrobial activity of polysaccharide films containing essential oils. Food Control. 22(8): 1302-1310. DOI 10.1016/j.foodcont.2011.02.004

Sawai, J., Igarashi, H., Hashimoto, A., Kokugan, T., Shimizu, M., 1995: Evaluation of growth-inhibitory effect of ceramics powder slurry on bacteria by conductance method. J. Chem. Eng. Jpn. 28(3): 288-293. DOI 10.1252/jcej.28.288

Sawai, J., Shoji, S., Igarashi, H., Hashimoto, A., Kokugan, T., Shimizu, M., Kojima, H., 1998: Hydrogen peroxide as an antibacterial factor in zinc oxide powder slurry. J. Ferment. Bioeng. 86(5): 521-522. DOI 10.1016/s0922-338x(98)80165-7

Sharma, V.K., Yngard, R.A., Lin, Y., 2009: Silver nanoparticles: Green synthesis and their antimicrobial activities. Adv. Colloid Interface Sci. 145(1-2): 83-96. DOI 10.1016/j.cis.2008.09.002

Shi, Z.L., Neoh, K.G., Kang, E.T., 2004: Surface-grafted viologen for precipitation of silver nanoparticles and their combined bactericidal activities. Langmuir. 20(16): 6847-6852. DOI 10.1021/la049132m

Schreurs, W.J.A., Rosenberg, H., 1982: Effect of silver ions on transport and retention of phosphate by escherichia-coli. J. Bacteriol. 152(1): 7-13.

Silver, S., 2003: Bacterial silver resistance: molecular biology and uses and misuses of silver compounds. Fems Microbiol. Rev. 27(2-3): 341-353. DOI 10.1016/s0168-6445(03)00047-0

Smita, S., Gupta, S.K., Bartonova, A., Dusinska, M., Gutleb, A.C., Rahman, Q., 2012: Nanoparticles in the environment: assessment using the causal diagram approach. Environ. Health. 11:1-11. DOI S1310.1186/1476-069x-11-s1-s13

Spallholz, J.E., Shriver, B.J., Reid, T.W., 2001: Dimethyldiselenide and methylseleninic acid generate superoxide in an in vitro chemiluminescence assay in the presence of glutathione: Implications for the anticarcinogenic activity of L-selenomethionine and L-Se-methylselenocysteine. Nutr. Cancer. 40(1): 34-41. DOI 10.1207/ s15327914nc401 8

Sudarshan, N.R., Hoover, D.G., Knorr, D., 1992: Antibacterial action of chitosan. Food Biotechnol. 6(3): 257-272.

Suzuki, K., Mikami, T., Okawa, Y., Tokoro, A., Suzuki, S., Suzuki, M., 1986: Antitumor effect of hexa-n-acetylchitohexaose and chitohexaose. Carbohydr. Res. 151(403-408. DOI 10.1016/s00086215(00)90359-8

Tartaj, P., Morales, M.D., Veintemillas-Verdaguer, S., Gonzalez-Carreno, T., Serna, C.J., 2003: The preparation of magnetic nanoparticles for applications in biomedicine. J. Phys. D-Appl. Phys. 36(13): R182-R197. DOI 10.1088/0022-3727/36/13/202

Tran, P.A., Webster, T.J., 2011: Selenium nanoparticles inhibit Staphylococcus aureus growth. Int. J. Nanomed. 6(1-10. DOI 10.2147/ijn.s21729

Tran, P.L., Hammond, A.A., Mosley, T., Cortez, J., Gray, T., Colmer-Hamood, J.A., Shashtri, M., Spallholz, J.E., Hamood, A.N., Reid, T.W., 2009: Organoselenium coating on cellulose inhibits the formation of biofilms by Pseudomonas aeruginosa and Staphylococcus aureus. Appl. Environ. Microbiol. 75(11): 3586-3592. DOI 10.1128/aem.02683-08

Wei, W.Q., Abnet, C.C., Qiao, Y.L., Dawsey, S.M., Dong, Z.W., Sun, X.D., Fan, J.H., Gunter, E.W., Taylor, P.R., Mark, S.D., 2004: Prospective study of serum selenium concentrations and esophageal and gastric cardia cancer, heart disease, stroke, and total death. Am. J. Clin. Nutr. 79(1): 80-85.

Wu, J.H., Ko, S.P., Liu, H.L., Jung, M.H., Lee, J.H., Ju, J.S., Kim Y.K., 2008: Sub $5 \mathrm{~nm}$ Fe3O4 nanocrystals via coprecipitation method. Colloid Surf. A-Physicochem. Eng. Asp. 313:268-272. DOI 10.1016/j.colsurfa.2007.04.108

Yang, J.J., Huang, K.H., Qin, S.Y., Wu, X.S., Zhao, Z.P., Chen, F., 2009: Antibacterial action of selenium-enriched probiotics against pathogenic Escherichia coli. Dig. Dis. Sci. 54(2): 246-254. DOI 10.1007/s10620-008-0361-4 